\title{
Evaluation of Tp-e interval, Tp-e/QT ratio and Tp-e/QTc ratio in patients with acute pancreatitis
}

\author{
Akut Pankreatitli Hastalarda Tp-e Aralığı, Tp-e/QT Oranı and Tp-e/QTc Oranı'nın \\ Değerlendirilmesi
}

Yilmaz Guler ${ }^{1 *}$, Can Ramazan Oncel $^{2}$

1 Alanya Alaaddin Keykubat University, Faculty of Medicine, Department of General Surgery, Alanya/Antalya,Turkey.

2 Alanya Alaaddin Keykubat University Faculty of Medicine, Department of Cardiology,Alanya/Antalya,Turkey.

\section{ABSTRACT}

Aim: Acute pancreatitis may affect cardiovascular system regardless of etiology. Electrocardiographic parameters such as QT interval, corrected QT interval (QTC), Tp-e interval and Tp-e/QT, Tp-e/QTc ratio can be used to evaluate myocardial repolarization. We aimed to investigate the effects of acute pancreatitis on the cardiovascular system and the relationship between ventricular repolarization parameters and the severity of the disease.

Methods: Ventricular repolarization parameters (QT interval, QTc interval, Tp-e/QT, Tp-e/QTc ratio) of the patients who were included in the study and diagnosed with acute pancreatitis were compared with the control group patients. In addition, these parameters and Ranson, APACHE II and amylase values were taken into account in all patients in the pancreatitis group and the relationship between the severity of the disease and cardiac parameters was investigated.

Results: 60 patients (30 acute pancreatitis and 30 control) were examined. Tp-e interval, Tp-e/QT and Tp-e/QTc ratios were significantly higher in the acute pancreatitis group compared to the control. In addition, Tp-e interval, Tp-e/QT and Tp-e/QTC ratios showed a positive correlation with the Ranson and APACHE II scores and Tp-e interval displayed a positive correlation with amylase levels.

Conclusions: Tp-e interval, Tp-e/QT and Tp-e/QTc ratios can be used as a marker for the detection of ventricular arrhythmia risk in acute pancreatitis patients and Tp-e/ QT and Tp-e/QTc ratios increased depending on the severity of AP and Tp-e interval increased in parallel with higher levels of amylase. Amylase level alone could be an indicator for increased risk of ventricular arrhythmia in patients with acute pancreatitis.

Keywords: Acute pancreatitis, Electrocardiography, Tp-e interval, Tp-e/QT ratio, Tp-e/QTc ratio

\section{ÖZ}

Amaç: Akut pankreatit etyolojisinden bağımsız olarak kardiyovasküler sistemi etkileyebilir. QT aralığı, düzeltilmiş QT aralığı (QTc), Tp-e aralığı ve Tp-e/QT, Tp-e/QTc oranları gibi elektrokardiyografik parametreler myokardiyal repolarizasyonun değerlendirilmesinde kullanılabilir. Çalışmamızda akut pankreatitin kardiyovasküler sistem üzerine olan etkilerini incelemeyi ve hastalığın ağırı̆̆ı ile ventriküler repolarizasyon parametreleri arasındaki ilişkiyi ortaya koymayı amaçladık.

Yöntemler: Akut pankreatit tanısı alan hastalarda ventriküler repolarizasyon parametreleri (QT aralığı, QTc aralığı, Tp-e/QT, Tp-e/QTc oranı) kontrol grubu hastaları ile karşılaştırıldı. Ayrıca tüm hastalarda bu parametreler yanında Ranson ve APACHE II skorları ile amilaz değerleri hesaplanarak hastalığın şiddeti ile kardiyak parametreler arasındaki ilişki incelendi.

Bulgular: Çalışmada 60 hasta (30 akut pankreatit ve 30 kontrol ) incelendi. Tp-e aralığı, Tp-e/QT ve Tp-e/QTc oranlarının akut pankreatitli hastalarda kontrol grubuna göre istatistiksel olarak anlamlı düzeyde daha yüksek olduğu tespit edildi. Ayrlca Tp-e aralığı, Tp-e/QT ve Tp-e/QTc oranlarının Ranson ve APACHE II skorları ile pozitif korelasyon gösterdiği, Tp-e aralığının amilaz düzeyi ile pozitif korelasyon gösterdiği tespit edildi.

Sonuç: Akut pankreatitli hastalarda Tp-e aralığı, Tp-e/QT ve Tp-e/QTc oranları ventriküler aritmi riskinin tespitinde kullanılabilir ve Tp-e/QT ve Tp-e/QTc oranlarının yükselmesi akut pankreatitin şiddetiyle doğru orantılı olup, Tp-e oranı amilaz düzeyi ile paralel olarak yükselmektedir. Tek başına amilaz düzeyi akut pankreatitli hastalarda ventriküler aritmi riskinin belirleyicisi olarak kullanılabilir.

Anahtar Kelimeler : Akut pankreatit, Elektrokardiyografi, Tp-e aralığı, Tp-e/QT oranı, Tp-e/QTc oranı

Received: 26.09.2019 Accepted: 27.12.2019 Published (Online):02.03.2020

* Corresponding author: Yilmaz Guler, Alanya Alaaddin Keykubat University, Faculty of Medicine Department of General Surgery, Alanya/Antalya, Turkey. Phone: +902425134841 e-mail: : yilmaz.guler@alanya.edu.tr

ORCID: 0000-0002-3225-6348

To cited: Güler Y, Öncel CR. Evaluation of Tp-e interval, Tp-e/QT ratio and Tp-e/QTc ratio in patients with acute pancreatitis. Acta Med. Alanya 2020;4(1):88-94. doi:10.30565/medalanya.625432 


\section{INTRODUCTION}

A cute pancreatitis (AP) is a sudden onset pancreatic inflammation that may manifest itself with local and systemic complications and is the 3rd most common gastrointestinal system disease in acute hospital admissions. It has a mortality rate of approximately $5 \%$ and is most commonly caused by gallbladder stones [1]. Different scoring methods are used to determine the severity of AP. Among these, the most commonly used pancreatitis-specific scoring system, the Ranson scoring method, is based on the evaluation of some clinical and laboratory parameters at the time of admission and at the 48th hour of hospitalization [2]. Another scoring method, APACHE II, allows the evaluation of the general condition and some physiological functions of the patients starting from the initial admission and grading at 24-hour intervals [3].

In patients with $\mathrm{AP}$, the cardiovascular system may be affected alone or in combination with other systems regardless of etiology. Cardiac rhythm disorders, myocardial contractility disorders, peripheral arterial-venous tone abnormalities are common cardiac manifestations of acute pancreatitis [4]. The pathophysiology of myocardial involvement in AP patients is not fully understood. In addition to systemic inflammatory response, cardiobiliary reflex, toxic effects of pancreatic enzymes on myocardium and coronary artery spasm are physiopathological mechanisms considered in the pathogenesis of cardiac involvement and electrocardiographic changes in acute pancreatitis. Arrhythmias, bradycardia, ST-T wave changes, depolarization and repolarization changes, including intraventricular conduction disturbances, are observed in these patients $[5,6]$.

Parameters such as QT interval, corrected QT interval (QTc), QT dispersion (QTd), and transmural dispersion of repolarization can be used to evaluate myocardial repolarization. Previous studies have shown that the duration between the peak of the $T$ wave and the end point (Tp-e interval) is considered as the total distribution index of repolarization. Similarly, the ratio of Tp-e interval to $Q T$ interval (Tp-e/QT) can be used as a reliable marker since it is not affected by heart rate changes in the evaluation of ventricular repolarization. In addition, Tp-e/QT ratio is considered to be a more reliable predictor of ventricular arrhythmogenesis compared to other parameters $[7,8]$.

In this study, we aimed to investigate the effects of acute pancreatitis on the cardiovascular system and the relationship between ventricular repolarization parameters and the severity of the disease.

\section{MATERIALS AND METHODS}

The study was performed on patients who were hospitalized and treated for AP between October 2017 and March 2019 in our General Surgery Clinic. Pancreatitis occurred due to biliary stone in all patients. Age, gender, height, weight, body mass index, systolic and diastolic blood pressures, pulse measurements, ejection fraction (EF) values, Ranson and APACHE II scoring values and laboratory parameters used for these scoring methods, along with amylase values measured at initial admission, were recorded. Abdominal ultrasound and abdominal CT scan were performed in all patients. Patients who were found to have cholecystitis at the time of admission and who had cholecystitis and/or pancreatitis attacks 1 month prior to admission, were excluded from the study. For the Ranson scoring, the scoring criteria of the patients at the first 5 hours and 48 hours were taken into consideration [2]. Scores of 4 and above were considered severe inflammation $[2,9]$. For APACHE II scoring however, scoring was performed by evaluating the patients' age, certain physiological characteristics and necessary laboratory parameters at 48 hours [3] and a score of 8 and above was considered as a severe case indicator $[3,9,10]$.

All patients underwent cardiac examination, echocardiography $(\mathrm{ECHO})$ and electrocardiography (ECG) prior to treatment within the first 24 hours of admission.

Electrocardiography: All patients had ECG at the time of admission and before treatment. A 12-lead surface ECG during sinus rhythm was obtained from each participant in supine position, following 10 minutes rest with $10 \mathrm{~mm} / \mathrm{mV}$ amplitude and 25 $\mathrm{mm} / \mathrm{s}$ paper speed. The QT interval was measured from the first deflection of the QRS complex to the 
end of the $T$ wave in as many leads as possible. Hodges formula $(\mathrm{QTc}=\mathrm{QT}+0.00175([60 / \mathrm{RR}]-60))$ was used to define corrected QT interval [11]. The Tp-e interval was defined as the interval from the peak of the T wave to the end of it. Measurement of the Tp-e interval was taken from precordial leads. The Tp-e/QT ratio was calculated as Tp-e interval divided by QT interval. Examples for measurement of QT and Tp-e interval presented at Figure 1. The software Cardio Calipers (Iconico Inc., New York, USA) was used for electrocardiographic measurements.

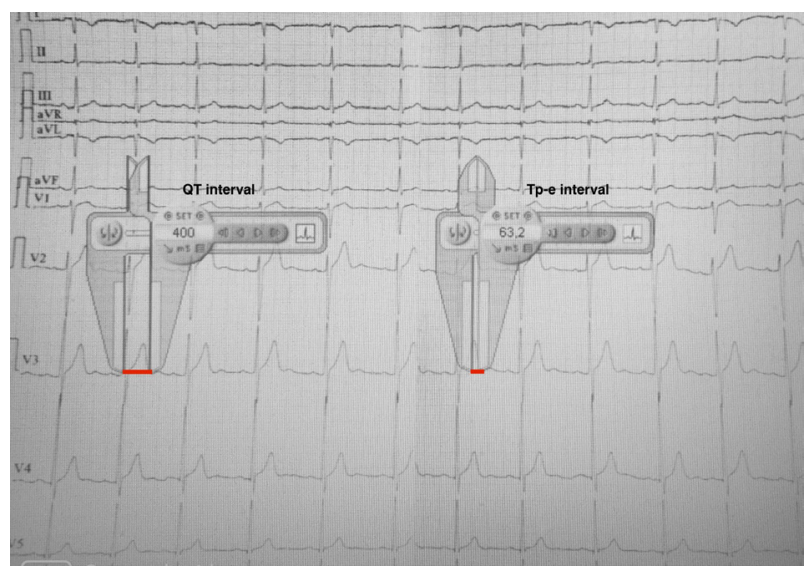

Figure 1. Examples for measurement of QT and Tp-e intervals

\section{Echocardiography:}

transthoracic echocardiographic examinations were performed in all participants at the left lateral decubitus position to evaluate conventional parameters, using Toshiba, Artida SSH-880 CV equipment (Japan). All echocardiographic measurements were done according to the guidelines of American Society of Echocardiography [12].

Exclusion Criteria were as follows: patients under 18 years of age, pregnant women, those receiving immunosuppressive therapy, regular steroid therapy, patients with choledocholithiasis, hepatic canal stone, obstructive jaundice, cholangitis, those with cholecystitis at the time of admission, those who developed cholecystitis and/or pancreatitis episodes in the last 1 month before admission and patients who underwent ERCP within the last 1 week. In addition, patients with known cardiovascular disease, congenital heart disease, metabolic-endocrine disease, renal disease, hypo-hyperthyroidism, diabetes mellitus, hypertension, acute-chronic respiratory diseases, rheumatologic disorders and use of medications that can affect electrocardiographic parameters, were excluded from the study. Furthermore, ECGs without clearly analyzable QT interval, corrected QT (QTC) interval, peak and the end of the T wave (Tp-e) and Tp-e/QT ratio were also excluded from the study.

The QT interval, QTc interval, Tp-e/QT, Tp-e/ QTc ratios of the patients who were included in the study and diagnosed with AP were compared with the control group patients. In addition, these parameters and Ranson, APACHE II and amylase values were taken into account in all patients in the pancreatitis group, and the relationship between the severity of the disease and cardiac parameters was investigated.

Statistical Analysis: Mean, standard deviation, median lowest, median highest, frequency and ratio values were used in descriptive statistics of the data. The distribution of variables was measured using the Kolmogorov-Smirnov test. In the analysis of quantitative independent data, independent samples $t$ test and Mann-Whitney $U$ test were used. The chi-square test was used for the analysis of qualitative independent data, and the Fischer test was performed when the chisquare test conditions were not met. Spearman's correlation analysis was used for correlation analysis and the SPSS 22.0 program was used for the statistical analyses.

\section{Ethical Approval}

This study was approved by the Ethics Committee of Alanya Alaaddin Keykubat University of Medical Sciences, all of the subjects' parents were informed regarding the details of the study and signed an informed consent form.

\section{RESULTS}

A total of 56 patients with acute pancreatitis were included in the study. Seventeen patients were diagnosed as cholecystitis with pancreatitis, 6 patients were diagnosed with choledochal stone, obstructive jaundice at the time of diagnosis, 1 patient was excluded from the study due to pregnancy and 2 patients were excluded because of previous pancreatitis attacks. The statistical analysis was performed on 60 patients, 30 in the AP patients group and 30 in the healthy control 
patients group. The gender distribution of the patients was $28(46.7 \%)$ females, $32(53.3 \%)$ males, and the mean age was $55(20-90)$ years. In the disease group, the Ranson score was between 1 and 4, the APACHE II score was between 3 and 10. The Ranson score was $4(13.3 \%)$ in 4 patients, the APACHE II score was 8 and above in 16 patients $(53.3 \%)$, and the amylase value ranged between 84 and 3010. The age, gender, demographic and medical data of the patients are presented in Table 1.

Age, gender, height, weight and BMI values of the patients in the AP and control groups were not significantly different $(p>0.05)$. There were no statistically significant differences in systolic blood pressure (SBP), diastolic blood pressure (DBP), heart rate (HR) and EF values between the groups $(p>0.05) . \mathrm{Hb}, \mathrm{BUN}$, creatinine, potassium, $\mathrm{Na}$ and $\mathrm{Ca}$ values were not significantly different in the AP and control groups ( $p>0.05)$. There was no significant difference in terms of QTc and QTc values between the AP and control group ( $p>0.05)$, whereas Tp-e values, Tp-e/QT values and Tp-e/ QTc ratios were significantly higher in the AP group compared to the control group $(p<0.05)$ (Figure 2). Data for AP and control groups are presented in Table 2.

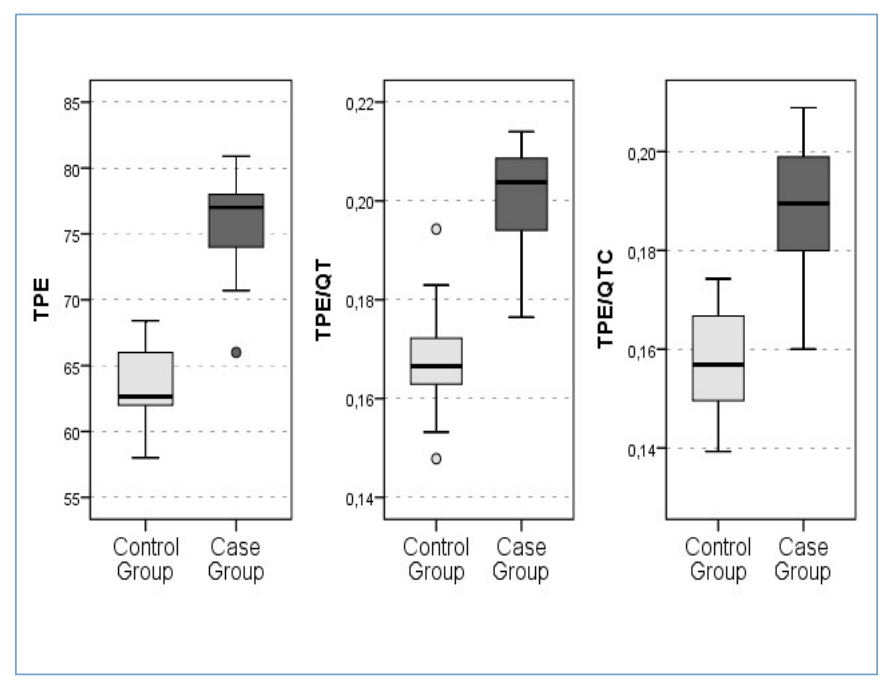

Figure 2. $\mathrm{Tp}$-e interval, $\mathrm{Tp}-\mathrm{e} / \mathrm{QT}$ ratio and $\mathrm{Tp}-\mathrm{e} / \mathrm{QTc}$ ratio were significantly higher in the acute pancreatitis group compared to the control group ( $\mathrm{p} \bowtie 0.05)$
Table 1. The age, gender, demographic and medical data of the patients

\begin{tabular}{|c|c|c|c|c|}
\hline & & Min-Max & Median & Mean $\pm s d / n-\%$ \\
\hline Age & & $20,0-90,0$ & 55,0 & $55,1 \pm 13,7$ \\
\hline Gen- & Female & & & $28 / 46,7 \%$ \\
\hline der & Male & & & $32 / 53,3 \%$ \\
\hline Length & & $150,0-190,0$ & 174,0 & $173,5 \pm 7,2$ \\
\hline Weight & & $52,0-120,0$ & 79,0 & $79,0 \pm 14,6$ \\
\hline BMI-k & $/ \mathrm{m}^{2}$ & $17,7-38,1$ & 25,3 & $26,1 \pm 4,4$ \\
\hline Ranson & & $0,0-4,0$ & 0,5 & $1,3 \pm 1,4$ \\
\hline Apache & & $3,0-10,0$ & 8,0 & $7,4 \pm 1,9$ \\
\hline SBP & & $100,0-140,0$ & 120,0 & $120,8 \pm 8,9$ \\
\hline DBP & & $60,0-85,0$ & 74,5 & $73,8 \pm 5,0$ \\
\hline HR & & $57,0-89,0$ & 72,0 & $73,4 \pm 7,2$ \\
\hline $\mathrm{Hb}$ & & $11,9-18,0$ & 15,0 & $14,9 \pm 1,2$ \\
\hline Bun & & $5,0-20,0$ & 12,2 & $12,2 \pm 3,3$ \\
\hline Creatin & & $0,6-1,1$ & 0,8 & $0,8 \pm 0,1$ \\
\hline Potassil & & $3,6-4,3$ & 4,0 & $4,0 \pm 0,2$ \\
\hline $\mathrm{EF}$ & & $57,0-82,0$ & 68,0 & $69,7 \pm 6,0$ \\
\hline $\mathrm{Na}$ & & $133,0-146,0$ & 138,0 & $138,8 \pm 2,8$ \\
\hline $\mathrm{Ca}$ & & $7,8-10,5$ & 9,2 & $9,2 \pm 0,5$ \\
\hline QT & & $350,0-402,0$ & 380,0 & $379,7 \pm 13,8$ \\
\hline QTc & & $359,8-444,8$ & 403,2 & $403,1 \pm 18,2$ \\
\hline TP-e & & $58,0-80,9$ & 68,3 & $69,7 \pm 6,9$ \\
\hline TP-e/Q & & $0,1-0,2$ & 0,2 & $0,2 \pm 0,0$ \\
\hline TP-e/Q & & $0,1-0,2$ & 0,2 & $0,2 \pm 0,0$ \\
\hline Amylas & & $84,0-3010,0$ & 1653,5 & $1709,1 \pm 1030,2$ \\
\hline Chole- & $(+)$ & & & $13 / 43,3 \%$ \\
\hline cystitis & $(-)$ & & & $17 / 56,7 \%$ \\
\hline
\end{tabular}

There was no significant correlation between QT and QTc intervals and Ranson score, Apache II score and amylase value $(p>0.05)$. There was a significant positive correlation between Tp-e interval and Ranson score, Apache score and Amylase value $(p<0.05)$. There was a significant positive correlation between $\mathrm{Tp}-\mathrm{e} / \mathrm{QT}$ ratio and Ranson and Apache II scores ( $p<0.05)$, however there was no significant correlation between Tp-e/QT ratio and amylase value. Similarly, there was a statistically significant positive correlation between Tp-e/QTc ratio and Ranson and Apache II scores $(p<0.05)$, but no significant correlation was found between Tp-e/QTc ratio and amylase value $(p>0.05)$. The correlation analysis between Ranson, Apache II and amylase values and calculated ECG parameters is shown in Table 3. 
Table 2. Demographic and medical data of the acute pancreatitis and control group patients

\begin{tabular}{|c|c|c|c|c|}
\hline & Control Group & Case Group & \multirow[t]{2}{*}{$\mathbf{P}$} \\
\hline & & $\begin{array}{l}\text { Mean } \pm s d / n-\% \\
\text { Median }\end{array}$ & $\begin{array}{l}\text { Mean } \pm s d / n-\% \\
\text { Median }\end{array}$ & \\
\hline \multicolumn{2}{|l|}{ Age } & $55,7 \pm 12,9 \quad 56,0$ & $54,4 \pm 14,6 / 55,0$ & $0,716^{\mathrm{m}}$ \\
\hline \multirow{2}{*}{$\begin{array}{l}\text { Gen- } \\
\text { der }\end{array}$} & Female & $14 / 46,7 \%$ & $14 / 46,7 \%$ & \multirow[t]{2}{*}{$1,000 x^{2}$} \\
\hline & Male & $16 / 53,3 \%$ & $16 / 53,3 \%$ & \\
\hline \multicolumn{2}{|c|}{ Length } & $173,9 \pm 6,7 / 174,0$ & $173,0 \pm 7,8 / 173,5$ & $0,621 \mathrm{~m}$ \\
\hline \multicolumn{2}{|c|}{ Weight } & $81,3 \pm 13,0 / 79,5$ & $76,6 \pm 16,0 / 77,5$ & $0,217 \mathrm{~m}$ \\
\hline \multicolumn{2}{|c|}{$\mathrm{BMI}-\mathrm{kg} / \mathrm{m}^{2}$} & $26,9 \pm 4,4 / 25,5$ & $25,2 \pm 4,4 / 25,1$ & $0,136^{\mathrm{m}}$ \\
\hline \multicolumn{2}{|c|}{ SBP } & $118,8 \pm 8,5 / 120,0$ & $122,9 \pm 8,9 / 120,0$ & $0,101^{m}$ \\
\hline \multicolumn{2}{|l|}{ DBP } & $73,8 \pm 6,7 / 75,0$ & $73,7 \pm 2,4 / 74,0$ & $0,652^{m}$ \\
\hline \multicolumn{2}{|l|}{ HR } & $73,8 \pm 8,9 / 74,5$ & $73,0 \pm 5,1 / 72,0$ & $0,646^{t}$ \\
\hline \multicolumn{2}{|l|}{$\mathrm{Hb}$} & $15,0 \pm 0,9 / 15,1$ & $14,8 \pm 1,4 / 14,7$ & $0,351^{t}$ \\
\hline \multicolumn{2}{|l|}{ Bun } & $12,9 \pm 2,5 / 13,0$ & $11,5 \pm 3,9 / 11,0$ & $0,095^{t}$ \\
\hline \multicolumn{2}{|c|}{ Creatinin } & $0,8 \pm 0,1 / 0,8$ & $0,8 \pm 0,1 / 0,8$ & $0,891^{\mathrm{t}}$ \\
\hline \multicolumn{2}{|c|}{ Potassium } & $3,9 \pm 0,2 / 4,0$ & $4,0 \pm 0,2 / 4,0$ & $0,518^{m}$ \\
\hline \multicolumn{2}{|l|}{ EF } & $70,3 \pm 5,8 / 69,0$ & $69,0 \pm 6,2 / 68,0$ & $0,303^{m}$ \\
\hline \multicolumn{2}{|l|}{$\mathrm{Na}$} & $138,4 \pm 2,8 / 138,0$ & $139,1 \pm 2,8 / 139,0$ & $0,238^{m}$ \\
\hline \multicolumn{2}{|l|}{$\mathrm{Ca}$} & $9,3 \pm 0,6 / 9,3$ & $9,1 \pm 0,5 / 9,1$ & $0,167 \mathrm{~m}$ \\
\hline \multicolumn{2}{|l|}{ QT } & $380,6 \pm 16,8 / 384,5$ & $378,8 \pm 10,1 / 378,7$ & $0,363^{m}$ \\
\hline \multicolumn{2}{|l|}{ QTc } & $404,8 \pm 22,3 / 404,4$ & $401,4 \pm 13,1 / 401,8$ & $0,615^{m}$ \\
\hline \multicolumn{2}{|l|}{ TP-e } & $63,5 \pm 2,9 / 2,7$ & $75,8 \pm 3,2 / 77,0$ & $0,000 \mathrm{~m}$ \\
\hline \multicolumn{2}{|c|}{ TP-e/QT } & $0,17 \pm 0,01 / 0,17$ & $0,20 \pm 0,01 / 0,20$ & $0,000 \mathrm{~m}$ \\
\hline \multicolumn{2}{|c|}{ TP-e/QTc } & $0,16 \pm 0,01 / 0,16$ & $0,19 \pm 0,01 / 0,19$ & $0,000^{m}$ \\
\hline
\end{tabular}

$\mathrm{t}: \mathrm{t}$ test / $\mathrm{m}$ :Mann-Whitney u test / $\mathrm{X}^{2}:$ Chi-square test

\section{DISCUSSION}

The pathogenesis of the effects of AP on different organs and systems, including the cardiovascular system, can be summarized in 3 stages. The first is the intrapancreatic trypsinogen activation and acinar cell injury as a result of trypsin secretion, the second involves intrapancreatic inflammation reaction development and various degrees of acinar cell necrosis, and the third encompasses development of SIRS and multiorgan dysfunction induced by the destruction of the enzymes, activated following inflammatory cell migration and endothelial adhesion as AP progresses [4]. Clinical studies of the effects of AP on the cardiovascular system have shown changes in the cardiac system such as hemodynamic status (hypovolemia-shock), electrocardiographic changes and pericardial effusion. Studies have shown interstitial edema and hypoxia in cardiomyocytes, increased contractility in myofibers, development of intracellular edema between cardiomyocytes, myocardial stromal collagenization, and cardiomyocyte hypertrophy in patients with AP [13].

Table 3. The correlation analysis between Ranson, Apache II and amylase values and ECG parameters

\begin{tabular}{|l|l|l|l|l|}
\hline \multirow{2}{*}{ QT } & & Ranson & Apache II & Amylase \\
\hline \multirow{2}{*}{ QTc } & $\mathrm{r}$ & $-0,132$ & $-0,067$ & 0,135 \\
\cline { 2 - 5 } & $\mathrm{p}$ & 0,313 & 0,724 & 0,478 \\
\hline \multirow{2}{*}{ TP-e } & $\mathrm{r}$ & $-0,113$ & $-0,142$ & $-0,175$ \\
\cline { 2 - 5 } & $\mathrm{p}$ & 0,388 & 0,455 & 0,355 \\
\hline \multirow{2}{*}{ TP-e/QT } & $\mathrm{r}$ & 0,895 & 0,730 & 0,618 \\
\cline { 2 - 5 } & $\mathrm{p}$ & 0,000 & 0,000 & 0,000 \\
\cline { 2 - 5 } & $\mathrm{p}$ & 0,869 & 0,507 & 0,253 \\
\hline \multirow{2}{*}{ TP-e/QTc } & $\mathrm{r}$ & 0,000 & 0,004 & 0,177 \\
\cline { 2 - 5 } & $\mathrm{p}$ & 0,868 & 0,518 & 0,450 \\
\hline
\end{tabular}

Spearman Correlation

Electrocardiographic changes may be seen in many patients with AP due to the impact of this disease on the cardiovascular system. In one study, it was reported that $57 \%$ of AP patients had transient ECG changes and the most common of these included non-specific ST-T wave changes and atrial or nodal rhythm changes. In this study, it was also found that ECG changes in biliary pancreatitis were more common $(80 \%)$ than in alcoholic pancreatitis and that this may be due to the fact that biliary pancreatitis is encountered more frequently in older subjects. It has been reported that ECG changes resembling ischemic heart disease findings may be due to stress induced by AP and/or imbalance in the autonomic nervous system [14]. In another study examining 65 patients with AP, the most common ECG change was found to be ST segment depression and $T$ wave inversion with a prevalence of $85 \%$. It was reported that AP could mimic myocardial infarction by causing ECG changes and elevation in several cardiac enzymes [15].

It has been reported that there may be numerous ECG changes including tachyarrhythmia, bradyarrhythmia, supraventricular premature contractions, shortening of PR interval, QRS prolongation, bundle branch blocks such as left bundle branch block, right bundle branch block and left anterior hemiblock, atrial flutter, decrease in $T$ wave voltage, ST segment abnormalities in AP patients and these changes are detected in approximately $50 \%$ of the cases [16]. The pathophysiology of ECG changes has been 
reported to be associated with myocardial damage caused by pancreatic proteolytic enzymes, vagal autonomic imbalance, metabolic and electrolyte abnormalities, hemodynamic instability, coronary arterial spasm, prothrombotic irregularities and systemic inflammatory response [4].

In our study, QT interval, QTc interval, Tp-e, Tp-e/ QT and Tp-e/QTc ratios in patients with AP are the electrocardiographic parameters that can be used as predictors of ventricular arrhythmias. Parameters such as QT interval, corrected QT interval and transmural dispersion of repolarization are used to detect myocardial repolarization by ECG. It is known that QT interval, considered as a cardiac electrical instability marker, is affected by myocardial ischemia, left ventricular dysfunction, neurohormonal activation, electrolyte and metabolic imbalance and some medications. Prolonged QT interval has been reported to increase the risk of arrhythmia and increase the risk of mortality in cardiac and non-cardiac diseases [17]. Tp-e interval which represents the interval between peak and end of $T$ wave in ECG can be used as total (transmural, apicobasal, global) index of repolarization dispersion. In addition, increased Tp-e interval can be used as an indicator of ventricular tachyarrhythmias and cardiovascular mortality. Tp-e/QT ratio, which is a current and new index, has been reported to be a more useful and effective index than QT interval, corrected QT interval and Tp-e interval in determining ventricular repolarization dispersion regardless of heart rate changes [18]. In addition, it was reported that Tp-e interval, Tp-e/QT and Tp-e/QTc ratios were significantly prolonged in patients with slow coronary flow compared to patients with normal coronary flow, and these new indices were positively correlated with reduced coronary flow [19].

Although there are many studies conducted on cardiovascular and ECG changes in patients with AP, according to our review there are no studies in the literature that investigated the new indices, namely Tp-e interval, Tp-e/QT and Tp-e/QTc ratios which can be used as markers of myocardial repolarization and ventricular arrhythmogenesis. In a study performed on QT interval measurement in patients with AP, QTc max and QTc dispersion values were increased in patients with acute biliary pancreatitis compared to healthy individuals, and this was found to be associated with the Ranson score. Furthermore, QT dispersion was increased in parallel with the severity of the disease [17]. In our study, QT interval, QTc interval, Tp-e interval and $\mathrm{Tp}-\mathrm{e} / \mathrm{QT}, \mathrm{Tp}-\mathrm{e} / \mathrm{QTc}$ ratios were examined in patients with acute biliary pancreatitis. While there was no statistically significant difference with regard to the QT and QTc intervals between the AP and control group patients, Tp-e interval, $T p-e / Q T$ and Tp-e/QTc ratios were significantly higher in the AP group compared to the control group. In addition, there was no correlation between the QT and QTc intervals in evaluation performed according to the Ranson and APACHE II scores, which we used to assess the severity of the disease. On the other hand, Tp-e interval, Tp-e/QT and Tp-e/QTc ratios showed a positive correlation with the Ranson and APACHE II scores. In addition to these scores, Tp-e interval displayed a positive correlation with amylase levels. As a result of these findings, Tp-e interval, Tp-e/QT and Tp-e/QTc ratios increased depending on the severity of AP and Tp-e interval increased in parallel with higher levels of amylase.

Although the exact mechanism of the relationship between disease severity and changes in myocardial repolarization and increased risk of ventricular arrhythmia is not known, it has been reported that this relationship may be due to the response of the cardiac system to abnormal proteolitic enzyme levels, vagal reflex, hypovolemia, toxic effects of cytokines and inflammatory mediators, microcirculation insufficiency caused by the increase in complement components and increased vascular permeability [20]. Another cause of QT interval prolongation has been reported to be the increase in the release of catecholamines due to disease and excessive pain and autonomic dysfunction [21,22]. The results obtained on the cardiac effects of AP vary, and it has been reported that left ventricular dysfunction may be due to increased pulmonary vascular resistance in patients with AP [23]. In one study, increased cardiac index was seen in severe necrotizing pancreatitis compared to edematous pancreatitis, but the mean pulmonary vascular resistance was reported to be low in patients with severe AP [24]. In another study, it was reported that prolonged $Q T$ interval and diastolic 
dysfunction are associated with high mortality in severe pancreatitis and these findings may be used to evaluate the severity of AP [25].

Study Limitations: This study was conducted in a single center. Our sample size was small to conduct a subgroup analysis according to the Ranson criteria. Intra and inter-observer variability analysis would have increased the reliability of ECG measurements.

In conclusion, along with Tp-e interval, one of the parameters that we investigated, new indices, Tp-e/QT and Tp-e/QTc ratios, are sensitive to myocardial repolarization and can be used as a marker for the detection of ventricular arrhythmia risk in various patient groups. Since Tp-e interval is positively correlated with Ranson and APACHE II scores as well as amylase values in patients with pancreatitis, it was concluded that high amylase level alone could be an indicator for increased risk of ventricular arrhythmia in patients with AP. Furthermore, Tp-e interval, Tp-e/QT and Tp-e/QTc ratios can be used as markers to determine the severity of the disease in patients with AP because of the positive correlation of these findings with the severity of the disease.

Conflict of Interest: The authors have no relevant conflicts of interest and received no financial support for this article.

Authors' contributions: All authors contributed to this project and article equally. All authors read and approved the final manuscript.

Acknowledgements: We thank all our patients who participated in this study.

\section{REFERENCES}

1. Aksoy F, Demiral G, Ekinci Ö Can The timing of laparoscopic cholecystectomy after biliary pancreatitis change the conversion rate to open surgery? Asian J Surg. 2018;41(4):307-312. PMID: 28284749

2. Ranson JH. Acute pancreatitis. In: Zinner MJ, Schwartz SI, Ellis H, Ashley SW, McFadden DW, editors. Maingot's abdominal operations. 10th ed. Stamford: Appleton \& Lange. 1997. p. 1899-915

3. Wilson C, Heath DI, Imrie CW. Prediction of outcome in acute pancreatitis: a comparative study of APACHE II, clinical assessment and multiple factor scoring systems. Br J Surg. 1990;77:1260-4. PMID: 2253005

4. Yegneswaran B, Kostis JB, Pitchumoni CS. Cardiovascular manifestations of acute pancreatitis. J Crit Care. 2011;26:225.e11-8. PMID:21185146

5. Rubio-Tapia A, García-Leiva J, Asensio-Lafuente E, Robles-Díaz G, Vargas-Vorácková F. Electrocardiographic abnormalities in patients with acute pancreatitis. J Clin Gastroenterol. 2005;39:815-8. PMID:16145345

6. Pezzilli R, Barakat B, Billi P, Bertaccini B. Electrocardiographic abnormalities in acute pancreatitis. Eur J Emerg Med. 1999;6:27-9. PMID:10340731

7. Kors JA, Ritsema van Eck HJ, van Herpen G. The meaning of the Tp-Te interval and its diagnostic value. J Electrocardiol. 2008;41:575-80. PMID:18954608

8. Gupta P, Patel C, Patel H, Narayanaswamy S, Malhotra B, Green JT, et al. T(p-e)/ QT ratio as an index of arrhythmogenesis. J Electrocardiol. 2008;41:567-74 PMID:18790499
9. Osvaldt AB, Viero P, Borges da Costa MS, Wendt LR, Bersch VP, Rohde L. Evaluation of Ranson, Glasgow, APACHE-II, and APACHE-O criteria to predict severity in acute biliary pancreatitis. Int Surg. 2001:86:158-61. PMID:11996072

10. Larvin M, McMahon MJ. APACHE-II score for assessment and monitoring of acute pancreatitis. Lancet. 1989;2:201-5. PMID:2568529

11. Hodges MS, Salerno D, Erlinen D. Bazett's QT correction reviewed: evidence that a linear QT correction for heart rate is better. J Am Coll Cardiol. 1983;1:694. DOI: https://doi.org/10.1161/JAHA.116.003264

12. Lang RM, Badano LP, Mor-Avi V, Afilalo J, Armstrong A, Ernande L, et al. Recommendations for cardiac chamber quantification by echocardiography in adults: an update from the American Society of Echocardiography and the European Association of Cardiovascular Imaging. J Am Soc Echocardiogr. 2015;28:1-39. PMID:25712077

13. Saulea A, Costin S, Rotari V. Heart ultrastructure in experimental acute pancreatitis. Rom J Physiol. 1997;34:35-44. PMID:9653808

14. Buch J, Buch A, Scmidt A. Transient ECG changes during acute attacks of pancreatitis. Acta Cardiol. 1980;35:381-90. PMID:6162302

15. Prasada R, Dhaka N, Bahl A, Yadav TD, Kochhar R Prevalence of cardiovascular dysfunction and its association with outcome in patients with acute pancreatitis. Indian J Gastroenterol. 2018;37(2):113-119. PMID:29560600

16. Yaylaci S, Kocayigit I, Genc AB, Cakar MA, Tamer A, Uslan MI. Electrocardiographic changes in patients with acute pancreatitis. Medical Journal of Dr. D.Y. Patil University. 2015;8(2): 196-198. DOI: 10.4103/0975-2870.153159

17. Ates F, Kosar F, Aksoy Y, Yildirim B, Sahin I, Hilmioglu F. QT interval analysis in patient with acute biliary pancreatitis. Pancreas. 2005;31(3):238-41. PMID:16163055

18. Alizade E, Yesin M, Yazicioğlu MV, Karaayvaz EB, Atici A, Arslan Ş et al. Evaluation of Tp-e Interval, Tp-e/QT Ratio, and Tpe/QTc Ratio in patients with asymptomatic right ventricular cardiomyopathy. Ann Noninvasive Electrocardiol. 2017;22(1). DOI: 10.1111/anec. 12362

19. Zehir R, Karabay CY, Kalaycı A, Akgün T, Kılıçgedik A, Kırma C. Evaluation of Tpe interval and Tpe/QT ratio in patients with slow coronary flow. Anatol J Cardiol. 2015;15(6):463-7. DOI: 10.5152/akd.2014.5503

20. James PR, Taggart P, McNally ST, Newman SP, Sproton SC, Hardman SM. Acute psychological stress and the propensity to ventricular arrhythmias. Eur Heart $\mathrm{J}$. 2002;21:1023-1028. PMID:10901515

21. Aytemir K, Aksoyek S, Ozer N, Gurlek A, Oto A. QT dispersion and autonomic nervous system function in patients with type 1 diabetes. Int J Cardiol. 1998;65:45-50. PMID:9699930

22. Wei K, Dorian P, Newman D, Langer A. Association between QT dispersion and autonomic dysfunction in patients with diabetes mellitus. J Am Coll Cardiol. 1995;26:859-863. PMID:7560609

23. Ito K, Ramirez-Schon G, Shah P, Agarwal N, Delguercio LR, Reynolds BM. Myocardial function in acute pancreatitis. Ann Surg. 1981;194:85-8. PMID:7247538

24. Beger HG, Bittner R, Buchler M, Hess W, Schmitz JE.. Hemodynamic data pattern in patients with acute pancreatitis. Gastroenterology. 1986;90:74-9. PMID:3940259

25. Nadkarni N, Bhasin DK, Rana SS, Bahl A, Sinha SK, Rao C, et al. Diastolic dysfunction, prolonged QTc interval and pericardial effusion as predictors of mortality in 